NBER WORKING PAPER SERIES

ON

HISTORICAL FACTORS IN LONG RUN GROWTH

\title{
THE USE OF HISTORICAL CENSUS DATA FOR MORTALITY AND FERTILITY RESEARCH
}

Michael R. Haines

Working Paper No. 31

\author{
NATIONAL BUREAU OF ECONOMIC RESEARCH \\ 1050 Massachusetts Avenue \\ Cambridge, MA 02138 \\ October 1991
}

\begin{abstract}
Paper prepared for the session "The U.S. Census in Historical Perspective: Privacy, Public-Use Samples, and Data Analysis-Contributed Papers" at the annual meetings of the American Statistical Association, August 18-22, 1991, Atlanta., GA. The author is the Banfi Vintners Professor of Economics at Colgate University. He wishes to thank the National Institute of Child Health and Human Development which funded some of the research on which this paper was based (grant 1 RO1 HD14359). The author also wishes to thank samuel H. Preston for his continuing and invaluable collaboration in much of this research. This paper is part of NBER's research program in Development of the American Economy. Any opinions expressed are those of the author and not those of the National Bureau of Economic Research.
\end{abstract}


NBER Working Paper \#31

October 1991

\title{
THE USE OF HISTORICAL CENSUS DATA FOR MORTALITY
} AND FERTILITY RESEARCH

\begin{abstract}
This paper illustrates the application of indirect techniques of fertility and mortality estimation to historical census data, both in published form and as micro census samples derived from the original enumerators' manuscripts. There are many instances in which census data exist but adequate vital registration data do not, such as in the United States prior to 1933, when the Birth and Death Registration Areas finally covered the entire nation. Since the United States has taken decennial censuses since 1790, and since all the original population schedules except those for 1890 have been preserved, it is possible to apply these indirect methods. For example, the censuses of 1900 and 1910 asked questions on children ever born, children surviving, and duration of current marriage, but this information was never tabulated or used for 1900 and only part $1 y$ tabulated for 1910. The Public Use Samples of the 1900 and 1910 censuses make possible the utilization of those data to estimate levels, differentials, and even recent trends in childhood mortality. Application of own-children methods to samples of the censuses since 1850 permits estimation of age-specific overall and marital fertility rates. Finally, the use of the 1900 Public Use Sample in conjunction with published data on parity from the 1910 census (or tabulations from the 1910 Public Use Sample) allows application of the two-census, parity increment method of birth rate estimation.
\end{abstract}

Michael R. Haines Department of Economics Colgate University 13 Oak Drive Hamilton, NY 13346 and NBER 
This paper illustrates the application of historical census data, both in published form and as micro samples derived from the original enumerators' manuscripts, to the problem of estimating fertility and mortality measures. There are many instances in which census data exist, but adequate vital registration data necessary for the estimation of fertility and mortality parameters (births, deaths, marriages) do not. Such was the case for the United States prior to 1933. In particular, the Constitution mandated a decennial census, and one has been taken in every tenth year since 1790 . The matter of vital registration was left up to the states, and, as a consequence, it was accomplished unevenly. Although some local areas (e.g., New York City) began registration quite early, the first state to do so was Massachusetts in 1842. A Death Registration Area (DRA) was not successfully formed until 1900 and then only included ten states and the District of Columbia. A Birth Registration Area was created in 1915. Both were complete only in 1933 (U.S. Bureau of the Census, 1971: 28-33).

Published census information is extensive and has allowed a great deal to be learned about demographic, social, and economic change in the United States in the nineteenth and twentieth centuries. For example, our knowledge of the American fertility decline by race, rural-urban residence, and geographic location is based largely on child-woman ratios from the census (Yasuba, 1962; Okun, 1958; Forster and Tucker, 1972; Easterlin, 1971; Engerman, 1978). Similarly, studies of the influence of various socio-economic factors on cross-sectional child-woman ratios has also made extensive use of published data (see, for example, Forster and Tucker, 1972; and Vinovskis, 1976, 1981, ch. 1 and passim for the pre-1860 period and Guest and Tolnay, 1983a, 1983b for the 1900 census). The land-availability hypothesis, the importance of literacy and education, and the effects of socio-economic structure on fertility have been explored using these data. 
More important for recent research, however, has been the use of samples of census manuscripts. Manuscripts of the federal censuses of population have, with the exception of most of the 1890 schedules, been preserved. Up to 1910 , they are publicly available on microfilm. Machine-readable, nationally representative public use samples of the population schedules are now available for 1900, 1910, and 1940-1980 (ICPSR, 1990). A similar public use sample is now being constructed for the 1880 federal schedules at the University of Minnesota (Ruggles, 1990). In addition, for the nineteenth century, many of the agricultural and manufacturing schedules are extant. Samples have been made from the 1860 manuscripts for both the northern and southern agricultural sectors and a sample of the 1880 manufacturing schedules is currently underway (Bateman and Foust, 1974; ICPSR, 1990: 273; Atack and Bateman, 1990). These manuscripts have furnished the raw materials for a number of studies of fertility, nuptiality, and even mortality.

To cope with the problems of missing and defective vital data, demographers have produced important advances in methods, including own-children fertility estimation, model life tables, models of fertility and nuptiality, and indirect techniques of fertility and child and adult mortality estimation (United Nations, 1983). These can be used with micro-level census samples to produce new estimates of birth and death rates for the nineteenth and early twentieth century United States.

Own-children methods were developed originally by Wilson Grabill to estimate agespecific fertility rates, as well as total fertility rates and gross and net reproduction rates from special samples of the 1940 and 1910 United States censuses (U.S. Bureau of the Census, 1944; Grabill and Cho, 1965). The method consists fundamentally in reconstituting families in the census manuscripts in order to assign children to their 
mothers. This assignment task is easier for the censuses of 1880 and after where the manuscripts provide information on name, age, sex, marital status, relationship to head of household, place of birth, and place of birth of mother and father for each individual. For 1900 and 1910, in addition, data are available on children ever born, children surviving, and duration of current marriage for adult women. Such information makes assignment of children to their mothers more straightforward, although not entirely without ambiguities. For the censuses of 1850 through 1870, data on marital status, relationship to household head, place of birth of parents (except for 1870), and fertility are lacking. In those cases, assignment is more difficult and uncertain, but feasible. Prior to 1850 , information was recorded for households and not individuals, so assignment is not really possible.

These own-children data can be used to produce crude and age-standardized marital and overall child-woman ratios. If more refined standard fertility measures are desired, then corrections can be made to the data (for underenumeration, for mortality, and for children missing from their mothers for reasons other than mortality) and the children and their mothers backward projected (United Nations, 1983: 182-195). Then total fertility rates, total marital fertility rates, gross reproduction rates, net reproduction rates, and age-specific overall and marital fertility rates can be estimated.

These methods have the great advantage that fertility measures can be calculated for characteristics of the mother, father, family, and/or geographic location, such as nativity, occupation, and labor force status, which are not necessarily characteristics of the child. A pioneering effort in this area was made by Hareven and Vinovskis (1975) for the 1880 census for portions of Boston. An own-children analysis of a sample of northern farm 
households from the 1860 census has shed further light on the land-availability hypothesis of fertility decline (Easterlin, Alter, and Condran, 1978). Work has also been completed for other areas of the United States in the nineteenth and early twentieth centuries (Hareven and Vinovskis, 1978; Haines, 1979a, chs. 4 and 6, 1980; Mason, Weinstein, and Laslett, 1985; Zunz, 1982; Wilcox and Golden, 1982; Ewbank, 1989; Morgan, Watkins, and Ewbank, forthcoming); but the method has not proven exceptionally popular, probably because of the large amount of data preparation involved. The method does seem to be relatively robust, however (Haines, 1989).

The appearance of the 1900 and 1910 United States census public use samples has enhanced efforts in fertility estimation. Tolnay, Guest, and Graham have produced refined fertility measures for native and foreign-born whites (Tolnay, Graham, and Guest, 1982) and for blacks (Tolnay, 1980, 1981) from the 1900 sample. In consequence we now have national and regional age-specific fertility estimates by race, ethnicity, and place of residence for the period 1886-1899. More recently, Morgan, Watkins, and Ewbank (forthcoming) have used the 1910 sample to explore ethnic variation in fertility just prior to World War I. The knowledge of the structure of fertility will allow a greater understanding of the mechanisms of fertility decline (e.g., the contributions of marriage versus marital fertility and of stopping versus spacing behavior) across racial and ethnic groups and across space.

These studies have confirmed the general fertility decline in the late nineteenth century, differentially higher fertility among foreign-born whites and blacks than among native whites, and relatively low fertility among urban blacks. In addition, multivariate analysis of published and sample census data revealed a strong relationship in the late 
nineteenth century between interstate fertility variation, on the one hand, and urbanindustrial structure and school attendance and labor force activity of children, on the other. Lower fertility was associated with larger cities, greater industrialization, less child labor force activity, and greater school attendance (Guest and Tolnay, 1983a, 1983b; Guest, 1981, 1982).

The finding of higher fertility among blacks and the foreign born has been reconfirmed for the periods $1900 / 10$ and $1905 / 10$ with an analysis using the 1900 census sample and published results from the sample of the 1910 census done for the 1940 census (Haines, 1989). Both the two census, parity increment method and own-children methods (United Nations, 1983: 58-64, 182-195) were applied, and refined and agespecific fertility measures derived for the first decade of the twentieth century. Interestingly, own-children methods seem less sensitive to defective data. The ownchildren estimates produced more stable and reasonable estimates, especially for older women. They are free, for example, of the tendency of women to understate parity at older ages. (This latter phenomenon is probably due to selective recollection of events distant in time and possibly psychologically painful, such as a child death.) Own-children estimates are also not terribly sensitive to choice of model life table families or other reasonable assumptions about mortality.

One novel application of historical parity data, the cohort-parity method, has been developed by Paul David, Warren Sanderson and colleagues and applied to the 1900 public use sample and the published data for the 1910 and 1940 United States censuses (David and Sanderson, 1987; David, et.al., 1988). It was necessary to correct the calculated mean parities for older women for selectivity due to mortality and marital 
dissolution. This was done by using a group of statistical models for correcting censored distributions, where the censoring is not independent of the attributes which are to be estimated. This provides a useful example of the application of sophisticated methods drawn from other disciplines (in this case, econometrics). Then the cohort-parity analysis was applied to these corrected data to estimate the proportion of the female population which had, or had not, controlled their fertility. It is possible to separate fertility controllers into "active" (i.e. those who actually did restrict family size) and "passive" (i.e. those who would control if it were necessary).

One of the unique features of this model is the incorporation of Page's (1977) observation that model marital fertility schedules which incorporate only age, and not marital duration, can produce misleading results. In particular, women marrying late seem to maintain higher age-specific marital fertility rates longer in their reproductive lives, possibly in order to "compensate" for a late start in childbearing. To correct for this, David and Sanderson have developed a model distribution of natural fertility by both age and marital duration using the 1911 census of Ireland. Using the cohort-parity method and the censuses of 1900,1910 , and 1940 , they are able to estimate the full distribution of completed marital parity, the proportion of American marriage cohorts 1855-59 to 1915-19 ever controlling actively during completed reproductive lifetimes, aggregate effectiveness of control (the ratio of active controllers to couples desiring control), and the mean completed parity of controlling and non-controlling women. This method makes use of both existing published data and new samples. One of the conclusions from this work is that spacing as well as stopping behavior were important in the nineteenth century American fertility transition (David and Sanderson, 1987). 
The study of American mortality in the late nineteenth century has been able to take considerable advantage of published data, despite the lack of a national registration system. For example, the federal censuses from 1850 to 1900 had a special mortality schedule which asked questions about deaths in the family in the year prior to the census. Despite obvious defects in the statistics (Condran and Crimmins, 1979; Crimmins, 1979), these data have proven useful. They were supplemented by vital registration from 1880 onwards and also provided cause of death information. It was possible, for example, to use these census death rates at certain ages in conjunction with published vital data for selected states and cities to construct new model life table estimates of mortality in the United States for the period 1850-1900 (Haines, 1979b). Both the Coale and Demeny (1966) and the Brass (Brass, 1975) one and two parameter model life table systems have proven useful in using such data.

Several authors have been able to use census mortality information to explore rural and urban mortality, cause of death, and public health in the late nineteenth century (Condran and Crimmins-Gardner, 1976, 1978, 1980; Crimmins and Condran, 1983; Higgs and Booth, 1979; Preston and Haines, 1991: ch. 1). Among the findings are (expectedly) higher urban mortality, especially among children; more rapid urban mortality declines in the 1890s; a large role for a few diseases (tuberculosis, diarrheal diseases, and several other infectious diseases) in accounting for higher urban mortality; some role for public health measures (especially water purification and sewerage disposal) in reducing mortality and accounting for differentials; and a reduction in racial and ethnic differentials once other factors are taken into account. The analysis of cause of death is particularly important in uncovering causal mechanisms (Crimmins and Condran, 1983; 
Preston and Haines, 1991: ch. 1). Census data on deaths rates by occupation have been used to investigate the hazards of work at the turn of the century (Uselding, 1976; Ransom and Sutch, 1986).

Information on children ever born and children surviving can also be used to estimate mortality. Perhaps the most common application is in the estimation of childhood mortality via systems of model life tables (United Nations, 1983: ch. III). These methods use the proportion of children who are dead to groups of women of particular ages or marriage durations, whose experience is adjusted for fertility patterns, to find a standard demographic parameter in a model life table system. The parameter is $\mathrm{q}(\mathrm{a})$, the proportion of children dying before age $\underline{\mathbf{a}}$. (Age a varies according to the age or marriage duration group of mothers chosen.) A variant of these methods is the backward projection of the age structure of surviving own children for some group of women (usually aged 20-34 years or married 0-14 years) to find the correct model life table which just equates total children ever born with the backward projected population (Preston and Haines, 1984).

These procedures have been applied to the public use samples of the 1900 and 1910 United States censuses, as well as to a sample of the 1900 census for the Pennsylvania anthracite mining region, samples of the 1900 and 1910 censuses for selected Texas counties, and a sample of the manuscripts of the 1865 New York state census (Haines, 1977; Preston and Haines, 1991; Preston, Ewbank, Hereward, forthcoming; Condran and Kramerow, forthcoming; Fliess and Gutmann, 1991). The application to the 1865 New York State census presents an interesting case, since the census only asked a question on children ever born. For younger women for whom the number of children surviving is 
very close to the number of own-children present in the home, it is possible to use data files with assigned own-children to estimate children surviving and then to use the backward projection technique (Haines, 1977). Thus even partial information can be made to yield useful mortality information.

Among the findings from these analyses are that child mortality was much lower in rural than in urban areas in the late nineteenth century. Also child mortality among blacks exceeded that among whites, but not by as much as is indicated by the $1900 / 02$ DRA life tables (Glover, 1921), largely because blacks in the DRA were almost all living in the less healthy urban areas whereas those in the South (which was, with the exception of the District of Columbia, not represented in the DRA) were living mainly in healthier rural areas. Child mortality was also higher among foreign-born whites and in certain regions of the United States, including the western South and New England.

A variant of this method uses the ratio of actual to expected child deaths to create a child mortality index (Preston and Haines, 1991; Haines, 1985; Preston, Ewbank, and Hereward, forthcoming; Condran and Kramerow, forthcoming; Fliess and Gutmann, 1991). Actual child deaths for each woman are readily available from the census (as the difference between children ever born and children surviving), and expected child deaths may be calculated by applying a standard model life table survivorship function to women of known parity and age or marriage duration. The 1900 and 1910 censuses provided information on the duration of current marriage for each married individual, thus making these public use samples considerably more valuable.

The index thus computed is useful both for tabulation and for multivariate analysis, since it can be calculated at both the group and at the individual level. In addition to 
establishing mortality levels and differentials, it is possible, using these methods, to estimate time trends for a period of about 15-20 years prior to the census (Preston and Haines, 1991: chs. $3 \& 4$ ). The index has a ready intuitive interpretation: values above one indicate above average child mortality, values close to or equal to one indicate average child mortality, and values below one point to below average child mortality. The index has the further virtue that the mortality of children can be related to characteristics of the parents or family (e.g. place of birth of mother or father), which is not always possible with vital statistics.

Some selected results from our study American child mortality using the 1900 national public use sample and the mortality index methodology are given in Table 1 (Preston and Haines, 1991). Such mortality estimates for the entire nation would not be possible without these new methods and this census sample, since vital statistics from the DRA only covered about $26 \%$ of the American population in 1900 . Also, published census results did not tabulate the information on parity, child survival, or marriage duration.

The DRA mortality data would tend to exaggerate black/white child mortality differentials because of the high proportion of blacks in high mortality urban areas in the DRA of $1900 / 02$ ( $82 \%$ of blacks in the DRA were urban versus about $20 \%$ for the nation as a whole). Table 1 shows that mortality among black children in the DRA was $48 \%$ higher than for the nation as a whole and $62 \%$ higher than for rural areas. This contrasts with black child mortality $100 \%$ higher in the DRA (and $84 \%$ higher in the urban portions of the DRA). The generally higher child mortality in the DRA for various ethnic groups, even controlling for size of place, is also evident in Table 1. 
Table 1 points out the higher child mortality in urban relative to rural areas. It is also clear that mortality increased with city size, with the exception of the largest cities. It seems that the largest cities were making significant progress in public health by 1900 (i.e. water purification, sewerage disposal, and some disease-specific programs). The benefits of child mortality reduction in the largest ten cities was disproportionately favoring children of the foreign born, since the relationship between child mortality and city size for the native white population was positive and monotonic. For the white population, the North Atlantic and South Central regions frequently had higher than average mortality, while the Midwest (North Central region) had more favorable mortality conditions, controlling for urban composition. (This was also true in multivariate analysis, controlling for a number of other covariates.)

An advantage of such own-children indirect mortality estimation is that characteristics of the parents can be assigned to the children. One such characteristic is foreign or native parentage. Vital registration usually did not report this historically for children, and the 1900/02 DRA life tables for foreign-born whites (Glover, 1921) only begin at age 10 , since most of the children of the foreign born were themselves native born. But the mortality conditions which affect the parents often affect the family generally, and hence the children of native and foreign-born parents could be expected to have experienced different mortality to the extent that their environments and socioeconomic conditions differed.

Table 1 shows that the children of foreign born whites did indeed suffer higher mortality at the turn of the century relative to the children of native whites, even controlling size of place of residence. This was not true relative to the black population, 
however, who consistently had lower child survival than either native or foreign-born whites. These findings are perhaps not too surprising, since child mortality is a good indicator of socioeconomic well-being, and the socioeconomic level of blacks and recent migrants was lower at the turn of the century. But a full multivariate analysis of the micro data (Preston and Haines, 1991: ch. 4) was not able completely to remove the effect of race and ethnicity by controlling for socioeconomic status, literacy, region, and residence.

Using another variant of these indirect child mortality estimation techniques, it is shown that mortality had been declining since the late nineteenth century for all ethnic groups with the possible exception of the blacks (Preston and Haines, 1991: ch. 4). This technique involves making mortality calculations for each marriage duration cohort of women, determining the average mortality regime to which they had been subject, and then dating these to the appropriate point in the past (United Nations, 1983: ch. III).

Another characteristic of the parents which can be used to cross-classify child mortality is occupation and labor force status. This makes it possible to use child mortality for the study of inequality by social class, to the extent that occupational groupings can be used to represent class. Child mortality is particularly appropriate for this, since it represents an outcome rather than a cause of inequality, such as income or wealth.

In a study comparing childhood mortality by social class in the United States in 1900 and in England and Wales in 1911, it was found that, regardless of the stratification schemes (i.e. occupational groupings) used, England and Wales was more "unequal" than the United States. That is, England and Wales showed greater variation in childhood 
mortality across father's occupational groupings than the United States. This outcome arose more because of relatively higher childhood mortality for white-collar and professional groups in the United States than because of a better situation for bluecollar groups. Also, occupational groupings alone had equal or greater power in explaining variation in child mortality across occupations of father than income, literacy, residence, or other variables available. (Haines, 1985; Preston and Haines, 1991: ch 5). A related analysis, making use of the 1900 and 1910 public use samples and published data for the DRA in the 1920s, has concluded that home health care practices were quite important in the American mortality decline in the early twentieth century (Ewbank and Preston, 1989).

It should be apparent that considerable use can be made of both published and manuscript historical census materials for the United States. Additional public use samples are underway (e.g., 1880) or in the planning stages (most likely 1920, 1850, and 1860). These combined with the existing wealth of published data, the public use samples of 1940-1990, and the continuing development of new methodologies should continue to advance our knowledge of fertility and mortality in the past. 


\section{REFERENCES}

Atack, Jeremy, and Fred Bateman. 1990. How Long Was the Work Day in 1880? National Bureau of Economic Research. Working Paper Series on Historical Factors in Long Run Growth. Working Paper No. 15. (October).

Bateman, Fred, and James D. Foust. 1974. "A Sample of Rural Households Selected from the 1860 Manuscript Censuses." Agricultural History. Vol. 48, No. 1. pp. 75-93.

Brass, William. 1975. Methods for Estimating Fertility and Mortality from Limited and Defective Data. Chapel Hill, NC: Carolina Population Center.

Coale, Ansley J., and Paul Demeny. 1966. Regional Model Life Tables and Stable Populations. Princeton, NJ: Princeton University Press.

Condran, Gretchen, and Eileen Crimmins. 1979. "A Description and Evaluation of Mortality Data in the Federal Census: 1850-1900." Historical Methods. Vol. 12, No. 1 (Winter). pp. 1-23.

Condran, Gretchen, and Eileen Crimmins-Gardner. 1976. "The United States Population in the Nineteenth Century: Mortality." Paper presented at the annual meetings of the Population Association of America, Montreal, Canada. (May).

Condran, Gretchen, and Eileen Crimmins-Gardner. 1978. "Public Health Measures and Mortality in U.S. Cities in the Late Nineteenth Century." Human Ecology. Vol. 6, No. 1 (March). pp. 27-54.

Condran, Gretch A., and Eileen M. Kramerow. Forthcoming. "Low Child Mortality in the United States in the Early Twentieth Century: An Examination of a Jewish Immigrant Population." Journal of Interdisciplinary History.

Condran, Gretchen, and Eileen Crimmins-Gardner. 1980. "Mortality Differentials between Rural and Urban Areas in the Northeastern United States, 1890-1900." Journal of Historical Geography. Vol. 6, No. 2. pp. 179-202.

Crimmins, Eileen M. 1979. "The Completeness of 1900 Mortality Data Collected by Registration and Enumeration for Rural and Urban Parts of States: Estimates Using the Chandra Sekar-Deming Technique." Unpublished paper.

Crimmins, Eileen, and Gretchen A. Condran. 1983. "Mortality Variation in U.S. Cities in 1900: a Two-Level Explanation by Cause of Death and Underlying Factors." Social Science History. Vol.7, No. 1 (Winter). pp. 31-59.

David, Paul A., Thomas A. Mroz, Warren C. Sanderson, Kenneth W. Wachter, and David R. Weir. "Cohort Parity Analysis: Statistical Estimates of the Extent of Fertility Control." 1988. Demography. Vol. 25, No. 2 (May). pp. 163-188.

David, Paul A., and Warren C. Sanderson. 1987. "The Emergence of a Two-Child Norm among American Birth Controllers." Population and Development Review. Vol. 13, No. 
1 (March). pp. 1-41.

Easterlin, Richard A. 1971. "Does Human Fertility Adjust to the Environment?" American Economic Review. Vol. 61, No 2 (May). pp. 399-407.

Easterlin, Richard A. 1977. "Population Issues in American Economic History: A Survey and Critique." In Robert Gallman, ed. Recent Developments in the Study of Business and Economic History: Essavs in Honor of Herman E. Krooss. Greenwich, CT: JAI Press. pp. 131-158.

Easterlin, Richard A., George Alter, and Gretchen Condran. 1978. "Farms and Farm Families in Old and New Areas: The Northern States in 1860." In Tamara K. Hareven and Maris A. Vinovskis, eds. Family and Population in Nineteenth-Century America. Princeton, NJ: Princeton University Press. pp. 22-84.

Engerman, Stanley L. 1978. "Changes in Black Fertility, 1880-1940." In Tamara K. Hareven and Maris A. Vinovskis, eds. Family and Population in Nineteenth-Century America. Princeton, NJ: Princeton University Press. pp. 126-153.

Ewbank, Douglas. 1989. "The Marital Fertility of American Whites before 1920." Unpublished manuscript. Population Studies Center, University of Pennsylvania. (June).

Ewbank, Douglas C., and Samuel H. Preston. 1989. "Persoanl Health Behavior and the Decline in Infant and Child Mortality: The United States, 1900-1930." Unpublished paper. Population Studies Center, University of Pennsylvania. (July).

Fliess, Kenneth P., and Myron P. Gutmann. 1991. "Ethnic Mortality Differentials in Texas, 1900 and 1910." Paper presented at the annual meetings of the Population Association of America, Washington, DC. (March).

Forster, Colin, and G.S.L. Tucker. 1972. Economic Opportunity and Whiter American Fertility Ratios, 1800-1860. New Haven: Yale University Press.

Glover, James W. 1921. United States Life Tables, 1890, 1901, 1910, and 1901-1910. Washington, DC: G.P.O.

Grabill, Wilson H., and Lee-Jay Cho. 1965. "Methodology for the Measurement of Current Fertility from Population Data on Young Children." Demographv. Vol. 2. pp. 50-73.

Guest, Avery M. 1981. "Social Structure and U.S. Interstate Fertility Differentials in 1900." Demography. Vol. 18, No. 4 (November). pp. 465-486.

Guest, Avery M. 1982. "Fertility Variation among U.S. Foreign Stock Population in 1900." International Migration Review. Vol. 16, Part 3, No. 59 (Fall). pp. 577-594

Guest, Avery M., and Stewart Tolnay. 1983a. "Urban Industrial Structure and Fertility: The Case of Large American Cities." The Journal of Interdisciplinary History. Vol. 13, No. 3 (Winter). pp. 387-409. 
Guest, Avery M., and Stewart Tolnay. 1983b. "Children's Roles and Fertility: Late Nineteenth Century United States." Social Science History. Vol. 7, No. 4 (Fall). pp. 355380.

Haines, Michael R. 1977. "Mortality in Nineteenth Century America: Estimates from New York and Pennsylvania Census Data, 1865 and 1900." Demography. Vol. 14, No. 3 (August). pp. 311-331.

Haines, Michael R. 1979a. Fertility and Occupation: Population Patterns in Industrialization. New York: Academic Press.

Haines, Michael R. 1979b. "The Use of Model Life Tables to Estimate Mortality for the United States in the Late Nineteenth Century." Demography. Vol. 16, No. 2 (May). pp. 289-312.

Haines, Michael R. 1980. "Fertility and Marriage in a Nineteenth Century Industrial City: Philadelphia, 1850-1880." The Journal of Economic History. Vol. 40, No. 1 (March). pp. 151-158.

Haines, Michael R. 1985. "Inequality and Childhood Mortality: A Comparison of England and Wales, 1911, and the United States, 1900." The Journal of Economic History. Vol. 45, No. 4 (December). pp. 885-912.

Haines, Michael R. 1989. "American Fertility in Transition: New Estimates of Birth Rates in the United States, 1900-1910." Demography. Vol. 26, No. 1 (February). pp. 137-148.

Hareven, Tamara K., and Maris A. Vinovskis. 1975. "Marital Fertility, Ethnicity, and Occupation in Urban Families: An Analysis of South Boston and the South End in 1880." Journal of Social History. Vol. 8 (March). pp. 69-93.

Hareven, Tamara K., and Maris A. Vinovskis. 1978. "Patterns of Childbearing in Late Nineteenth-Century America: The Determinants of Marital Fertility in Five Massachusetts Towns in 1880." In Tamara K. Hareven and Maris A. Vinovskis, eds. Family and Population in Nineteenth-Century America. Princeton, NJ: Princeton University Press. pp.85-125.

Higgs, Robert, and David Booth. 1979. "Mortality Differentials within Large American Cities in 1890." Human Ecology. Vol. 7 No. 4 (December). pp. 353-370.

ICPSR (Inter-university Consortium for Political and Social Research. 1990. Guide to Resources and Services: 1990-1991. Ann Arbor, MI: ICPSR.

Mason, Karen Oppenheim, Maxine Weinstein, and Barbara Laslett. 1985. "The Decline of Fertility in Los Angeles, California, 1880-1900." Research Report No. 85-83. Population Studies Center. University of Michigan. (July).

Morgan, S. Philip, Susan Cotts Watkins, and Douglas Ewbank. Forthcoming. "Generating Americans: Ethnic Differences in Fertility." In Susan Cotts Watkins, ed. After Ellis Island: A 1910 Census Monograph. NY: Russell Sage. 
Okun, Bernard. 1958. Trends in Birth Rates in the United States since 1870. Baltimore: The Johns Hopkins University Press.

Page, Hilary J. 1977. "Patterns Underlying Fertility Schedules: A Decomposition by Both Age and Marital Duration." Population Studies. Vol. 31, No. 1. pp. 85-106.

Preston, Samuel H., Douglas C. Ewbank, and Mark Hereward. Forthcoming. "Child Mortality Differences by Ethnicity and Race." In Susan Cotts Watkins, ed. After Ellis Island: A 1910 Census Monograph. NY: Russell Sage.

Preston, Samuel H., and Michael R. Haines. 1984. "New Estimates of Child Mortality in the United States at the Turn of the Century." Journal of the American Statistical Association. Vol. 79, No. 386 (June). pp. 272-281.

Preston, Samuel H., and Michael R. Haines. 1991. Fatal Years: Child Mortality in LateNineteenth Century America. Princeton, NJ: Princeton University Press.

Ransom, Roger L., and Richard Sutch. 1986. "The Labor of Older Americans: Retirement of Men On and Off the Job, 1870-1937." The Journal of Economic History. Vol. XLVI, No. 1 (March). pp. 1-30.

Ruggles, Steven. 1990. 1880 Public Use Sample: User's Guide. Social History Research Laboratory. Working Paper. University of Minnesota. October.

Tolnay, Stewart E. 1980. "Black Fertility in Decline: Urban Differentials in 1900." Social Biology. Vol. 27, No. 4 (Winter). pp. 249-260.

Tolnay, Stewart E. 1981. "Trends in Total and Marital Fertility for Black Americans, 18861899." Demography. Vol. 18, No. 4 (November). pp. 443-463.

Tolnay, Stewart E., Stephen N. Graham, and Avery M. Guest. 1982. "Own-child Estimates of U.S. White Fertility, 1886-99." Historical Methods. Vol. 15, No. 3 (Summer). pp. 127138.

United Nations. 1983. Indirect Techniques for Demographic Estimation. Manual X. New York: United Nations.

U.S. Bureau of the Census. 1944. Sixteenth Census of the United States: 1940. Population. "Differential Fertility, 1940 and 1910: Standardized Fertility Rates and Reproduction Rates." Washington, DC: G.P.O.

U.S. Bureau of the Census. 1971. The Methods and Materials of Demography. By Henry S. Shryock, Jacob S. Siegal, and Associates. Washington, DC: G.P.O.

Uselding, Paul. 1976. "In Dispraise of Muckrakers: United States Occupational Mortality, 1890-1910." Research in Economic History. Vol. 1. pp. 334-371.

Vinovskis, Maris A. 1976. "Socioeconomic Determinants of Interstate Fertility Differentials 
in the United States in 1850 and 1860." The Journal of Interdisciplinary History. Vol. 6, No. 3 (Winter). pp. 375-396.

Vinovskis, Maris A. 1981. Fertility in Massachusetts from the Revolution to the Civil War. New York: Academic Press.

Wilcox, Jerry, and Hilda H. Golden. 1982. "Prolific Immigrants and Dwindling Natives?: Fertility Patterns in Western Massachusetts, 1850 and 1880." Journal of Family History. Vol. 7, No. 3 (Fall). pp. 265-288.

Yasuba, Yasukichi. 1962. Birth Rates of the White Population of the United States, 18001860: An Economic Analysis. Baltimore: The Johns Hopkins University Press.

Zunz, Olivier. 1982. The Changing Face of Inequality: Urbanization. Industrial Development, and Immigrants in Detroit, 1880-1920. Chicago: University of Chicago Press. 
TABLE 1. Child Mortality by Race \& Nativity of Mother, Size of Place, \& Region of Residence. Married Women, Married 0-24 Years. United States \& Death Registration Area. 1900.(a)

\begin{tabular}{|c|c|c|c|c|c|c|c|}
\hline & Urban & $\begin{array}{l}\text { Top } 10 \\
\text { Cities }\end{array}$ & $\begin{array}{l}\text { Other } \\
\text { Cities } \\
25,000+\end{array}$ & $\begin{array}{l}5,000- \\
24,999\end{array}$ & $\begin{array}{r}1,000- \\
4,999\end{array}$ & Rural & TOTAL \\
\hline $\begin{array}{l}\text { UNITED STATES } \\
\text { AI women } \\
\text { White } \\
\text { Native White } \\
\text { Foreign-born White } \\
\text { Black }\end{array}$ & $\begin{array}{l}1.1263 \\
1.0709 \\
0.9732 \\
1.2093 \\
1.9654\end{array}$ & $\begin{array}{l}1.1445 \\
1.1425 \\
1.1172 \\
1.1641 \\
1.4208\end{array}$ & $\begin{array}{l}1.2813 \\
1.1955 \\
1.0676 \\
1.3529 \\
2.4203\end{array}$ & $\begin{array}{l}1.0994 \\
1.0108 \\
0.8981 \\
1.2143 \\
1.9713\end{array}$ & $\begin{array}{l}0.9270 \\
0.8634 \\
0.8266 \\
0.9887 \\
1.5863\end{array}$ & $\begin{array}{l}0.9290 \\
0.8312 \\
0.8077 \\
0.9601 \\
1.3382\end{array}$ & $\begin{array}{l}1.0088 \\
0.9404 \\
0.8698 \\
1.1315 \\
1.4650\end{array}$ \\
\hline \multicolumn{8}{|l|}{$\begin{array}{c}\text { DEATH REGISTRATION } \\
\text { AREA (b) }\end{array}$} \\
\hline $\begin{array}{l}\text { A11 Women } \\
\text { White } \\
\text { Native White } \\
\text { Foreign-born White } \\
\text { Black }\end{array}$ & $\begin{array}{l}1.1571 \\
1.1426 \\
1.0184 \\
1.2542 \\
2.1329\end{array}$ & $\begin{array}{l}1.2312 \\
1.2296 \\
1.2777 \\
1.2025 \\
\star\end{array}$ & $\begin{array}{l}1.2900 \\
1.2650 \\
1.0988 \\
1.3972 \\
2.0639\end{array}$ & $\begin{array}{l}1.0272 \\
1.0076 \\
0.8153 \\
1.2320 \\
\star\end{array}$ & $\begin{array}{l}0.9090 \\
0.9013 \\
0.8396 \\
1.0549 \\
\star\end{array}$ & $\begin{array}{l}0.8862 \\
0.8715 \\
0.8263 \\
1.0779 \\
\star\end{array}$ & $\begin{array}{l}1.0828 \\
1.0681 \\
0.9445 \\
1.2296 \\
2.1751\end{array}$ \\
\hline $\begin{array}{l}\text { REGIONS: WHITE WOMEN } \\
\text { North Atlantic } \\
\text { North Central } \\
\text { South Atlant ic } \\
\text { South Central } \\
\text { West }\end{array}$ & $\begin{array}{l}1.0709 \\
1.1490 \\
0.9790 \\
1.0750 \\
1.0978 \\
0.9321\end{array}$ & $\begin{array}{l}1.1425 \\
1.2124 \\
0.9990 \\
1.2637 \\
--. \\
1.0071\end{array}$ & $\begin{array}{l}1.1955 \\
1.2858 \\
1.0843 \\
0.9594 \\
1.2380 \\
1.1996\end{array}$ & $\begin{array}{l}1.0108 \\
0.9819 \\
1.0657 \\
0.8993 \\
1.1619 \\
0.6308\end{array}$ & $\begin{array}{l}0.8634 \\
0.9338 \\
0.7680 \\
1.1053 \\
0.9262 \\
0.7658\end{array}$ & $\begin{array}{l}0.8312 \\
0.8831 \\
0.7746 \\
0.8017 \\
0.8993 \\
0.9236\end{array}$ & $\begin{array}{l}0.9404 \\
1.0808 \\
0.8579 \\
0.8673 \\
0.9472 \\
0.9216\end{array}$ \\
\hline
\end{tabular}

SOURCE: Sample of census enumerators' manuscripts.

a. The mortality index is the ratio of actual to expected child deaths to women in each group. The index is calculated for all currently married women, married less than 25 years. Expected child deaths is the national average for women in each marriage duration group. The average age of child is about 5-6 years.

b. The Death Registration Area of 1900 consisted of Maine, New Hampshire, Vermont, Massachusetts, Rhode Island, Connecticut, New York, New Jersey, Michigan, Indiana, and the District of Columbia.

* Fewer than 40 children ever born for the cell.

-. Not available. 